LingTera
Available online at: http://journal.uny.ac.id/index.php/litp
LingTera, 6 (1), 2019, 8-16

\title{
Pengaruh bahasa Inggris ragam lisan guru, media, dan sumber belajar terhadap kemampuan listening comprehension siswa
}

\author{
Eka Oktarini $^{1} *$, Pujiyati Suyata ${ }^{2}$ \\ ${ }^{1}$ SMP Negeri 1 Toli-Toli. Jalan Magamu No. 35, Toli-Toli, Sulawesi Tengah 94514, Indonesia. \\ ${ }^{2}$ Universitas Ahmad Dahlan. Jl. Kapas No.9, Umbulharjo, Yogyakarta, 55166, Indonesia \\ * Coresponding Author. E-mail: eka8rini@gmail.com \\ Received: 22 October 2016; Revision: 7 April 2019; Accepted: 18 June 2019
}

\begin{abstract}
Abstrak
Penelitian ini memiliki tujuan yakni untuk mengetahui pengaruh intensitas penggunaan bahasa Inggris ragam lisan, pemanfaatan media pembelajaran, dan kelengkapan sumber belajar terhadap kemampuan listening comprehension siswa SMP di Kabupaten Sleman. Penelitian ini adalah penelitian Ex-post Facto. Sampel yang dipilih sebanyak 370 siswa, dengan menggunakan teknik stratified proportional cluster random sampling. Instrumen penelitian menggunakan angket dan tes. Kualitas intrumen yang digunakan adalah IRT dengan menggunakan program QUEST. Data dianalisis dengan teknik statistik Regresi Ganda yang diteruskan dengan Korelasi Parsial. Hasil penelitian menunjukkan bahwa penggunaan bahasa Inggris ragam lisan, intensitas pemanfaatan media,dan kelengkapan sumber belajar mempengaruhi kemampuan listening comprehension Siswa SMP di Kabupaten Sleman dengan nilai analisis Regresi $(\mathrm{F}=0,038 \mathrm{p} \leq 0,05)$. Pengaruh penggunaan bahasa Inggris ragam lisan terhadap kemampuan listening comprehension adalah sebesar 12,6\% dengan nilai Korelasi Parsial $(r=0,126$, sig. $\mathrm{p} \leq 0,05$, Beta 0,126$)$. Pengaruh Intensitas pemanfaatan media terhadap kemampuan listening comprehension adalah sebesar 0,8\% dengan nilai Korelasi Parsial $(\mathrm{r}=-$ 0,080,Sig. $\mathrm{p} \leq 0,05$, Beta $-0,080$ ). Dan pengaruh kelengkapan sumber terhadap kemampuan listening comprehension sebesar 1,4\% dengan nilai Korelasi Parsial ( $r=-0,014$, Sig. $p \leq 0,05$ Beta -0,014).
\end{abstract}

Kata Kunci: listening comprehension, bahasa Inggris ragam lisan, pemanfaatan media

\section{The effect of teachers' spoken English variety, media, and learning sources on the ability of students' listening comprehension}

\begin{abstract}
This study has fourobjectives. First is to investigate the gathering effect of of English spoken language, the intensity of the use of media, and completeness of learning resources on the ability of listening comprehension in Sleman Junior high school students. The other objectives are the effect of each variable on the ability of listening comprehension Junior high school students in Sleman District. This research is an ex-post facto research.The sample consisted of 370 students were selected using stratified proportional random sampling techniques. The research instruments were questionnaire and tests. IRT was used to know the quality of instrumen by using QUEST program. The data were analyzed by using the Multiple Regression and Partial Correlation statistic analysis.The result of analysis indicates that the use of English spoken language, the intensity of the use of media, and completeness of learning resources together combined affect the listening comprehension.with Reression value $(F=0.038$, sig. with $p \leq 0.05)$. The result of each variable on the listening comprehension indicates that the use of English spoken language affects $12.6 \%$ with score ( $r=$ 0.126 , sig. $p \leq 0.05$, Beta 0.126). the intensity of using media affects $0.8 \%$ with score $(r=-0.080$, Sig. $p \leq$ 0.05 , Beta -0.080).And completeness of learning resources affect $1.4 \%$ with score $(r=-0.014$, Sig. $p \leq 0.05$ Beta-0.014).
\end{abstract}

Keywords: listening comprehension, English spoken language, use of media

How to Cite: Oktarini, E., \& Suyata, P. (2019). Pengaruh bahasa Inggris ragam lisan guru, media, dan sumber belajar terhadap kemampuan listening comprehension siswa. LingTera, 6(1), 8-16. doi:https://doi.org/10.21831/lt.v6i1.11337

This is an open access article under the CC-BY-SA license. 


\section{LingTera,6 (1), 2019 - 9}

Eka Oktarini, Pujiyati Suyata

\section{PENDAHULUAN}

Keterampilan listening merupakan keterampilan yang paling sering digunakan dan merupakan tahapan yang penting dalam pemerolehan bahasa kedua (Maharani \& Astuti, 2018). Dunkell \& Lim (2006, p. vii) menyatakan bahwa Listening merupakan kompetensi kebahasaan yang ditargetkan dikuasai dalam pembelajaran untuk siswa dalam tahap-tahap awal pembelajaran bahasa kedua sebelum kompetensi kebahasaan yang lain. Siswa dapat memperoleh informasi dengan mendengarkan guru atau siswa lain. Namun, pembelajaran listening disebut sebagai pelajaran yang membosankan dan menjenuhkan (Assapari, 2014). Siswa merasa kesulitan sebelum mencoba pelajaran listening. Kelas listening selalu identik dengan mendengarkan dan menyebutkan atau mengisi titik-titik pada lembar jawaban.

Ruang lingkup dalam pembelajaran bahasa Inggris di SMP terdiri atas keterampilan reseptif yang meliputi keterampilan menyimak (listening), dan keterampilan membaca (reading), sedangkan keterampilan produktif meliputi keterampilan berbicara (speaking) dan keterampilan menulis (writing). Keterampilan menyimak (listening) merupakan keterampilan paling awal diajarkan di SMP berdasarkan Kurikulum Tingkat Satuan Pendidikan. Menyimak merupakan salah satu keterampilan berbahasa diantara empat keterampilan. Namun seringkali menyimak terlihat seperti agak dikesampingkan dalam pelajaran-pelajaran berbahasa. Padahal kegiatan menyimak ini berperan penting dalam pengembangan kemampuan berbahasa seseorang terutama para siswa, golongan muda, yang akan menjadi penerus bangsa. Pembelajaran menyimak bukanlah semata-mata penyajian materi dengan mendengarkan segala sesuatu informasi, melainkan ada proses pemahaman yang harus dikembangkan (Schultz, 2003, p.9). Jika ingin membandingkan dengan berbicara, menulis, serta membaca, pembelajaran menyimak memiliki tingkat kesulitan yang tidak kalah jika dibandingkan dengan ketiga komponen tersebut.

Mengingat pentingnya kemampuan listening, para peneliti mencoba untuk menemukan cara meningkatkan kemampuan listening dengan menerapkan beberapa teknik dalam pengajaran. Salah satu upaya yaitu Ragam bahasa lisan adalah bahan yang dihasilkan alat ucap (organ of speech) dengan fonem sebagai unsur dasar. Dalam ragam lisan, guru berurusan dengan tata bahasa, kosakata, dan lafal (Prayitno, 2014;
Qurniawati \& Nurhayati, 2015, Sinaga, 2017). Dalam ragam bahasa lisan ini, pembicara dapat memanfaatkan tinggi rendah suara atau tekanan, air muka, gerak tangan atau isyarat untuk mengungkapkan ide. Namun, terdapat pandangan kontradiktif mengenai penggunaan L1 dalam pembelajaran bahasa Inggris sebagai bahasa asing atau biasa dikenal dengan EFL (English as Foreign Language).

Pendekatan monolingual akan selalu menegaskan pentingnya penggunaan The English Only demi mencapai tujuan pembelajaran bahasa Inggris yang efektif, ini berarti penggunaan L1 dalam pembelajaran EFL harus dilarang sedapat mungkin. (Krashen, 2002, p.67) dalam bukunya Second language acquisition and second language learning mendukung pendekatan ini dengan argumentasi bahwa setiap orang yang belajar bahasa asing akan mengikuti pola yang sama sebagaimana ia mempelajari bahasa pertamanya, sehingga penggunaan bahasa pertama harus diminimalkan dalam pembelajaran bahasa asing tersebut.

Penulis buku pengajaran EFL seperti Jeremy Harmer tidak menganggap penting isu ini, bagi mereka penggunaan bahasa pertama tidak memiliki peran berarti dalam pengajaran EFL (Harmer, 2003, p.66). Faktanya saat ini telah ada gerakan besar yang mulai menjauh dari pemahaman The English Only yang selama ini telah menjadi bagian dari pendekatan atau metode pengajaran bahasa, sehingga pertanyaan yang akhirnya muncul di antaranya adalah: Apakah penggunaan bahasa Inggris ragam lisan di kelas dapat mempengaruhi pemerolehan bahasa kedua? apakah L1 masih diperlukan dalam pembelajaran bahasa Inggris di kelas? atau, apakah sebaiknya menggunakan bahasa Inggris sebagai satu-satunya bahasa pengantar dalam pembelajaran bahasa Inggris di kelas. Memahami fenomena tersebut perlu pendeskripsian yang terfokus pada beberapa aspek yaitu aspek penggunaan bahasa yakni intensitas penggunaan bahasa Inggris di dalam tujuan pedagogis, yang meliputi instruction, explanation, dan interaction. Serta aspek bentuk-bentuk bahasa (speech act) yang mencakup interference, borrowing, mixing dan code switching.

Bahasa Inggris merupakan bahasa asing yang tidak umum digunakan dalam kehidupan siswa sehari-hari. Di Sleman sendiri siswa menggunakan Bahasa Indonesia dan Jawa. Sekolah adalah satu-satunya tempat untuk guru memaksimalkan penggunaan bahasa Inggris bagi siswa 
karena terbatasnya akses siswa dalam pemerolehan bahasa.

Proses pemerolehan bahasa pada pada pembelajaran bahasa kedua dapat terjadi apabila masukan (input) itu dapat dipahami (comprehensible). Comprehensible input itu bisa didapatkan melalui tuturan yang dapat dipahami maknanya. Untuk memahami input itu pembelajaran bisa dibantu dengan penguasaan tata bahasa yang telah diperoleh sebelumnya, pengetahuan tentang dunia, penjelasan dan bantuan terjemahan dalam proses belajar mengajar (Krashen, 2002, p.57). Potensi dari kelas bahasa kedua dalam peranya sebagai sumber utama dari comprehensible input akan mendorong pemerolehan bahasa pada siswa, terutama jika mereka mempunyai akses yang terbatas pada lingkungan informal.

Krashen (2002, p.64) menjelaskan tiga cara yang bisa digunakan guru untuk memfasilitasi input dalam pengajaran di kelas agar para siswa dapat lebih paham maksud dan tujuan pembelajaran. Yaitu: (1) Artikulasi yang lebih lambat dan jelas dapat membantu siswa dalam mengidentifikasi kata-kata dengan lebih mudah. (2) lebih banyak menggunakan kosa kata, mengurangi slank, dan penggunaan idiom yang lebih sedikit. (3) penyederhanaan sintaks dan kalimat yang lebih pendek.

Guru dalam hal ini merupakan salah satu faktor penentu dalam pencapaian tujuan pendidikan serta peningkatkan mutu pendidikan di sekolah (Barber \& Mourshed, 2007, p.16). Guru juga bertindak sebagai fasilitator yang membantu terciptanya kondisi kondusif bagi peserta didik juga mempunyai tugas utama sebagai pengajar. Oleh sebab itu, guru sebaiknya dapat melaksanakan tugas mengajar sebagaimana yang diharapkan sehinnga akan berpengaruh pada peningkatan kemampuan menyimak siswa. Sebelum mengajar seorang guru sebaiknya mempunyai perencanaan pengajaran terutama dalam hal pemanfaatan media.

Media merupakan alat bantu yang dipakai dalam rangka memberikan pengalaman konkret dan mempertinggi daya serap siswa terhadap pelajaran. Seperti pribahasa Tiongkok "When I am told I forget, What I see I remember and What I do I builds a castle in my head" (Benson \& Odera, 2013, p.12). Ungkapan tersebut menjelaskan proses yang sama dengan proses pembelajaran di kelas. Jika siswa hanya diberi penjelasan saja, mereka akan gampang lupa. Jika mereka diberi kesempatan untuk melihat objek yang dijelaskan, mereka akan ingat. Jika mereka mempraktikan apa yang didengar mereka akan mem- bentuk pola pikirnya dalam melihat makna secara nyata. Penggunaan media memberikan siswa pengalaman atau pejanan berbahasa (Language exposure) yang dapat merangsang suatu tindak bahasa (speech act). Karena memberikan pengalaman-pengalaman yang membantu dalam pemerolehan bahasa membuat masukan atau input yang diterima lebih mudah dipahami (comprehensible input) oleh anak-anak.

Dikaitkan dengan pembelajaran, media dimaknai sebagai alat komunikasi yang digunakan dalam proses pembelajaran untuk membawa informasi berupa materi ajar dari pengajar kepada peserta didik sehingga peserta didik menjadi lebih tertarik untuk mengikuti kegiatan pembelajaran. Media pembelajaran merupakan komponen intruksional yang meliputi pesan, orang, dan peralatan. media merupakan wahana penyalur informasi belajar atau informasi pesan.

Dalam perkembangannya media pembelajaran mengikuti perkembangan teknologi. (Djamarah \& Zain, 2006, p.123). Berdasarkan perkembangan teknologi tersebut, mereka juga mengelompokkan media pembelajaran ke dalam empat kelompok, yaitu: Media hasil teknologi cetak, media hasil teknologi audio-visual, media hasil teknologi yang berdasarkan komputer dan media hasil gabungan teknologi cetak dan teknologi komputer.

Memadukan kegiatan mendengarkan dalam pembelajaran bahasa Inggris dengan penggunaan teknologi multimedia dapat menjadi opsi yang praktis dalam proses belajar mengajar. Kekuatan penggunaan media dalam pembelajaran listening telah diketahui sejak dulu. Terdapat beberapa penelitian sebelumnya bahwa penggunaan media berperan dalam proses Listening. Seperti penelitian Hsu, Hwang, Chang, \& Chang (2013) tentang efek penggunaan video pada kemampuan listening comprehension, Leveridge dan Yang (2013) mengenai pembelajaran listening comprehension dengan menggunakan multimedia pada siswa EFL dan Choirunnisa \& Haryadi (2015) tentang pengembangan media pembelajaran bahasa Inggris berbasis komputer untuk keterampilan menyimak bagi siswa SMA.

Kemampuan seseorang pada dasarnya dipengaruhi oleh berbagai faktor yang saling terkait satu dengan yang lain. Jadi tidak ada faktor tunggal yang secara otomatis dan berdiri sendiri mempengaruhi dan menentukan kemampuan menyimak belajar seseorang. Seperti kelengkapan sumber belajar di sekolah, (Sudjana \& Rivai, 2010, p.77) menyatakan bahwa sumber belajar adalah segala daya yang dapat diman- 
faatkan guna memberikan kemudahan kepada seseorang dalam belajarnya. Sumber belajar yang digunakan dapat berupa bahan baku penunjang, contohnya guru, buku pelajaran, majalah, koran, televisi, dan internet.

Kaitan antara sumber belajar dan Kemampuan menyimak sangat erat. Menurut Goh (2002, p.43) sumber belajar dapat memberikan manfaat yang besar dalam menentukan kemampuan menyimak siswa. Manfaat sumber belajar adalah mampu membantu peserta didik untuk memahami materi, dan memberikan pengalaman langsung kepada peserta didik serta memudahkan belajar secara umum. Namun berdasarkan observasi awal, peneliti melihat bahwa penggunaan sumber belajar yang memadai di sekolah masih kurang atau tidak dimanfaatkan secara maksimal.

Menurut Mulyasa (2002, pp.49-50) sumber belajar memiliki fungsi penting dalam proses belajar. Sumber belajar meningkatkan produktivitas pembelajaran dengan jalan mempercepat laju belajar dan membantu guru untuk menggunakan waktu secara lebih baik. Mengurangi beban guru dalam menyajikan informasi, sehingga dapat lebih banyak membina dan mengembangkan gairah belajar. Sumber belajar juga dapat mengurangi kontrol guru yang kaku dan tradisional dan memberikan kesempatan bagi siswa untuk berkembang sesuai dengan kemampuannya. Sehingga dengan memantapkan pembelajaran, dengan jalan meningkatkan kemampuan sumber belajar dapat membantu guru dalam menyajikan informasi dan bahan secara lebih kongkrit. Fungsi-fungsi tersebut sekaligus menggambarkan tentang pentingnya kelengkapan sumber belajar untuk kepentingan proses dan pencapaian hasil pembelajaran siswa.

Berdasarkan uraian tersebut perlu untuk mengetahui bagaimana pengaruh intensitas peng- gunaan bahasa Inggris di dalam kelas, pemanfaatan media yang ada serta kelengkapan sumber belajar di sekolah yang mempengaruhi kemampuan menyimak para siswa di sekolah menengah pertama di Kabupaten Sleman sebagai daerah yang letaknya strategis dalam menyokong Kota Yogyakarta sebagai kota pendidikan.

\section{METODE}

Jenis penelitian ini adalah penelitian $e x$ post facto dengan rancangan korelasional. Penelitian ini bertujuan untuk mengetahui pengaruh intensitas penggunaan bahasa Inggris ragam lisan, pemanfaatan media pembelajaran, dan kelengkapan sumber belajar terhadap kemampuan listening comprehension siswa SMP di Kabupaten Sleman.

Waktu dan tempat penelitian ini dilaksanakan pada kelas VIII SMP negeri Kabupaten Sleman Yogyakarta. Rentang penelitian dini dilakukan selama bulan November 2015 sampai Januari 2016. Populasi pada penelitian ini adalah seluruh siswa kelas VIII SMP negeri yang ada di Kabupaten Sleman tahun ajaran 2015/2016. Jumlah populasi seluruhnya adalah 7786 siswa dari 54 SMP negeri di Kabupaten Sleman.

Teknik yang digunakan dalam menentukan sampel adalah stratified proporsional cluster simple random sampling. Pengambilan sampel dimulai dari mengelompokkan SMP negeri di Kabupaten Sleman berdasarkan nilai ujian bahasa Inggris pada Ujian Nasional kemudian data dikelompokan ke dalam tingkatan tinggi, sedang dan rendah (Tabel 1). Sampel dalam penelitian ini berjumlah 370 siswa. Penentuan ukuran sampel menggunakan rumus Krejcie \& Morgan (1970).

Tabel 1. Kategori dan Pengambilan Sampel dari SMP Negeri di Kabupaten Sleman

\begin{tabular}{cccccccc}
\hline \multirow{2}{*}{ No. } & \multirow{2}{*}{ Stratified } & \multicolumn{2}{c}{ Proportional } & \multicolumn{2}{c}{ Cluster } & \multicolumn{2}{c}{ Simple random sampling } \\
\cline { 3 - 7 } & & \multirow{2}{*}{ Jumlah Sekolah } & $\begin{array}{c}\text { Sampel } \\
\text { sekolah }\end{array}$ & Jumlah Kelas & $\begin{array}{c}\text { Sampel } \\
\text { Kelas }\end{array}$ & Jumlah siswa & $\begin{array}{c}\text { Sampel } \\
\text { siswa }\end{array}$ \\
\hline 1. & Level Tinggi & 15 & 2 & 9 & 5 & 160 & 110 \\
2. & Level Sedang & 17 & 2 & 10 & 5 & 160 & 110 \\
3. & Level Rendah & 22 & 3 & 14 & 7 & 224 & 150 \\
& Total & 54 & 7 & 44 & 17 & 544 & 370 \\
\hline
\end{tabular}

Tabel 2. Deskripsi dari Variabel Kemampuan Listening Comprehension

\begin{tabular}{|c|c|c|c|c|}
\hline No. & Skor & Kategori & Frekuensi & $\%$ \\
\hline 1. & $\mathrm{X} \geq \dot{\mathrm{x}}+1 . \mathrm{SD}$ & Tinggi (score $\geq 63,967$ ) & 57 & $15 \%$ \\
\hline 2. & $\dot{\mathrm{x}}+1 . \mathrm{SD}>\mathrm{X} \geq \dot{\mathrm{x}}$ & Cukup (score $63,96 \geq 49,06$ ) & 118 & $32 \%$ \\
\hline 3. & $\dot{\mathrm{x}}>\mathrm{X} \geq \dot{\mathrm{x}}-1 . \mathrm{SD}$ & Kurang (score $49,06 \geq 34,16$ ) & 135 & $36 \%$ \\
\hline \multirow[t]{2}{*}{4.} & $\mathrm{X}<\dot{\mathrm{X}}-1 . \mathrm{SD}$ & Rendah (score $<34,16$ ) & 60 & $16 \%$ \\
\hline & & Total & 370 & $100 \%$ \\
\hline
\end{tabular}


Data tentang variabel bebas (X1, X2, X3) yang diteliti berupa intensitas penggunaan bahasa Inggris ragam lisan guru, intensitas pemanfaatan media pembelajaran, dan kelengkapan sumber belajar. Adapun teknik pengumpulan data yang digunakan dalam penelitian ini adalah tes dan angket. Jenis tes yang akan digunakan dalam penelitian ini adalah tes objektif. Tes objektif digunakan untuk mengukur kemampuan listening comprehension siswa. Test terdiri atas test pilihan ganda yang disusun berdasarkan kurikulum KTSP. Untuk melakukan tes listening comprehension siswa, proses penelitian akan menggunakan alat bantu berupa alat pengeras suara atau speaker. Angket digunakan untuk mengumpulkan data penggunaan bahasa Inggris ragam lisan, intensitas pemanfaatan media pembelajaran dan kelengkapan sumber belajar di sekolah. Diharapkan dengan angket penelitian ini dapat menggali banyak informasi dari subjek yang berkaitan secara langsung dengan masalah penelitian yang menjadi fokus utama dalam penelitian ini.

Uji validitas dan reabilitas instrumen test yaitu soal listening comprehension digunakan uji validitas isi (content validity) lewat pendapat ahli (expert judgement). Setelah mendapat persetujuan pendapat ahli, soal diujicobakan pada kelas VIII di luar sampel dan butir soal dianalisis dengan program QUEST. Hasil perhitungan menyatakan bahwa tingkat kesulitan dari instrumen tes dalam kategori sedang. Hasil alat tes berdasarkan MNSQ nilai INFIT dengan kriteria penerimaan > 0,77-1,30 (Subali \& Suyata, 2012, p.61) batas penerimaan kriteria item menunjukkan fit atau cocok dengan Rasch Model atau 1-PL. Hasil analisis item berdasarkan analisis QUEST untuk listening comprehension adalah 28 butir soal yang valid dari 32 butir soal yang diujicobakan.

Uji validitas instrumen penelitian berupa lembar angket tentang intensitas penggunaan bahasa Inggris ragam lisan guru, intensitas pemanfaatan media pembelajaran, dan kelengkapan sumber belajar di sekolah yaitu menggunakan uji validitas konstruk (construct validity) lewat pendapat ahli (expert judgment). Setelah menggunakan pendapat ahli, uji validitas konstruk dilakukan dengan analisis faktor dengan alat uji $K M O$ and Bartlett Test dengan menggunakan bantuan program komputer SPSS 20. Setelah mendapatkan data empirik (data uji coba).

Teknik analisis data yang digunakan dalam penelitian ini adalah metode analisis data des- kriptif kuantitatif. Alat analisis data yang digunakan adalah Program Quest dan SPSS versi 20. Teknik analisis data yang digunakan adalah analisis Regresi Ganda. Asumsi klasik yang sering digunakan para ahli statistika adalah uji normalitas, uji linearitas, uji heterokedastisitas, uji multikolinieritas.

\section{HASIL DAN PEMBAHASAN}

Gambaran karakteristik tentang intensitas penggunaan bahasa Inggris ragam lisan guru, intensitas pemanfaatan media pembelajaran, kelengkapan sumber belajar dan kemampuan listening comprehension.

\section{Deskripsi dari Variabel Kemampuan Listening Comprehension}

Hasil dari 28 nomor tes kemampuan listening comprehension menunjukkan bahwa nilai yang paling tinggi adalah 86 , nilai yang paling rendah adalah 14 , nilai mean 49,06 , nilai median 46,00, nilai mode 50 dan nilai standar deviasi adalah 14,904. Detail informasi tentang distribusi frekuensi dapat dilihat pada Tabel 2.

Tabel 2 menunjukkan bahwa terdapat 57 siswa (15\%) dalam kategori Tinggi. 118 siswa (36\%) dalam kategori Cukup. Terdapat 135 murid (36\%) dalam kategori Kurang dan 60 siswa (16\%) dalam kategori rendah. Bisa disimpulkan bahwa kemampuan listening comprehension siswa masih kurang karena hampir terdapat lebih banyak siswa dalam kategori kurang dalam kemampuan listening comprehension.

\section{Deskripsi dari Penggunaan Bahasa Inggris Ragam Lisan}

Hasil dari 26 nomor angket dari penggunaan bahasa Inggris ragam lisan menunjukkan bahwa nilai yang paling tinggi adalah 129 , nilai yang paling rendah adalah 37 , nilai mean 89,35 , nilai median 90,00, nilai mode 91 dan nilai dari standar deviasi adalah 10,236. Detail informasi tentang distribusi frekuensi dapat dilihat pada Tabel 3.

Tabel 3 menunjukkan bahwa terdapat 63 siswa (17\%) dalam kategori tinggi. 156 siswa (42\%) dalam kategori cukup. Terdapat 104 siswa (28\%) dalam kategori kurang dan 47 siswa (13\%) dalam kategori rendah. Bisa disimpulkan bahwa penggunaan bahasa Inggris ragam lisan guru di sekolah cukup tinggi karena hampir semua nilai dalam kategori cukup. 
LingTera,6 (1), 2019 - 13

Eka Oktarini, Pujiyati Suyata

Tabel 3. Kategori Nilai dari Penggunaan Bahasa Inggris Ragam Lisan

\begin{tabular}{|c|c|c|c|c|}
\hline No. & Skor & Kategori & Frekuensi & $\%$ \\
\hline 1. & $\mathrm{X} \geq \dot{\mathrm{x}}+1 . \mathrm{SD}$ & Tinggi ( score $\geq 99,566$ ) & 63 & $17 \%$ \\
\hline 2. & $\dot{\mathrm{x}}+1 . \mathrm{SD}>\mathrm{X} \geq \dot{\mathrm{x}}$ & Cukup (score $\geq 89,35$ ) & 156 & $42 \%$ \\
\hline 3. & $\dot{\mathrm{X}}>\mathrm{X} \geq \dot{\mathrm{x}}-1 . \mathrm{SD}$ & Kurang ( score $\geq 79,09$ ) & 104 & $28 \%$ \\
\hline 4. & $X<\dot{x}-1 . S D$ & Rendah $($ score $<70,09)$ & 47 & $13 \%$ \\
\hline \multicolumn{3}{|c|}{ Total } & 370 & $100 \%$ \\
\hline
\end{tabular}

Tabel 4. Kategori Nilai dari Pemanfaatan Media Pembelajaran

\begin{tabular}{clrrr}
\hline No. & Skor & Kategori & Frekuensi & $\%$ \\
\hline 1. & $\mathrm{X} \geq \dot{\mathrm{x}}+1 . \mathrm{SD}$ & Tinggi (score $\geq 95,91)$ & 49 & $13 \%$ \\
2. & $\dot{\mathrm{X}}+1 . \mathrm{SD}>\mathrm{X} \geq \dot{\mathrm{x}}$ & Cukup (score $\geq 75,85)$ & 172 & $46 \%$ \\
3. & $\dot{\mathrm{X}}>\mathrm{X} \geq \dot{\mathrm{x}}-1 . \mathrm{SD}$ & Kurang (score $\geq 55,789)$ & 70 & $19 \%$ \\
4. & $\mathrm{X}<\dot{\mathrm{x}}-1 . \mathrm{SD}$ & Rendah (score $<55,789)$ & 79 & $21 \%$ \\
& & & $\mathbf{3 7 0}$ & $\mathbf{1 0 0 \%}$ \\
\hline
\end{tabular}

Tabel 5. Skor Kategori dari Kelengkapan Sumber Belajar

\begin{tabular}{|c|c|c|c|c|}
\hline No. & Skor & Kategori & Frekuensi & $\%$ \\
\hline 1. & $X \geq \dot{x}+1 . S D$ & Tinggi (score $\geq 105,83$ ) & 78 & $21 \%$ \\
\hline 2. & $\dot{\mathrm{x}}+1 . \mathrm{SD}>\mathrm{X} \geq \dot{\mathrm{x}}$ & Cukup (score $\geq 92,25$ ) & 166 & $45 \%$ \\
\hline 3. & $\dot{\mathrm{x}}>\mathrm{X} \geq \dot{\mathrm{x}}-1 . \mathrm{SD}$ & Kurang $($ score $\geq 78,67$ ) & 91 & $25 \%$ \\
\hline 4. & $\mathrm{X}<\dot{\mathrm{X}}-1 . \mathrm{SD}$ & Rendah (score $<78,67$ ) & 35 & $9 \%$ \\
\hline \multicolumn{3}{|c|}{ Total } & 370 & $100 \%$ \\
\hline
\end{tabular}

\section{Deskripsi dari Pemanfaatan Media Pembelajaran}

Hasil dari 28 nomor angket dari pemanfaatan media pembelajaran menunjukkan bahwa nilai yang paling tinggi adalah 117 , nilai yang paling rendah adalah 26 , nilai mean 75,85 , nilai median 80,00, nilai mode 86 dan nilai dari standar deviasi adalah 20,061. Detail informasi tentang distribusi frekuensi dapat dilihat pada Tabel 4

Tabel 4 menunjukkan bahwa terdapat 49 siswa (13\%) dalam kategori Tinggi. 172 siswa (46\%) dalam kategori cukup. Terdapat 70 siswa (19\%) dalam kategori kurang dan 79 siswa (21\%) dalam kategori rendah. Bisa disimpulkan bahwa pemanfaatan media pembelajaran siswa cukup tinggi karena hampir semua siswa dalam kategori cukup.

\section{Deskripsi dari Ketersediaan Sumber Belajar}

Hasil dari 30 nomor angket dari ketersediaan sumber belajar menunjukkan bahwa nilai yang paling tinggi adalah 139 , nilai yang paling rendah adalah 17 , nilai mean 92,25 , nilai median 97,00 , nilai mode 103 dan nilai dari standar deviasi adalah 13,580. Detail informasi tentang distribusi frekuensi dapat dilihat pada Tabel 5.

Tabel 5 menunjukkan bahwa terdapat 78 siswa $(21 \%)$ dalam kategori tinggi. 166 siswa (45\%) dalam kategori cukup. Terdapat 91 siswa (25\%) dalam kategori kurang dan 35 siswa (9\%) dalam kategori rendah. Bisa disimpulkan bahwa ketersediaan sumber belajar siswa tinggi karena hampir semua siswa dalam kategori cukup tinggi.

Sebelum menganalisis data dengan regresi berganda, data yang ada harus diuji dengan beberapa tes. Uji tes yang digunakan adalah uji normalitas (Tabel 6), uji linearitas (Tabel 7), uji heterokedastisitas (Gambar 1) dan uji multikolinearitas (Tabel 8).

Tabel 6. Uji Normalitas

\begin{tabular}{clc}
\hline No. & \multicolumn{1}{c}{ Variabel } & Hasil \\
\hline 1. & $\begin{array}{l}\text { Kemampuan listening } \\
\text { comprehension }\end{array}$ & 0,071 \\
2. & $\begin{array}{l}\text { Penggunaan bahasa Inggris ragam } \\
\text { lisan }\end{array}$ & 0,127 \\
3. & Intensitas pemanfaatan media & 0,082 \\
4. & Kelengkapan sumber belajar & 0,118 \\
\hline
\end{tabular}

Berdasarkan hasil uji normalitas menggunakan uji Kolmogorof Smirnov terlihat bahwa nilai signifikansi yang dihasilkan pada masingmasing variabel lebih besar dari $\alpha=0,05$ ( $p$ > $0,05)$ maka dapat disimpulkan bahwa sebaran masing-masing variabel dalam penelitian ini berdistribusi normal.

Tabel 7. Uji Linearitas

\begin{tabular}{cccc}
\hline No. & Variabel & Sig. Dev. From Linearity & Kesimpulan \\
\hline 1. & $\mathrm{X} 1-\mathrm{Y}$ & 0,792 & Linear \\
2. & $\mathrm{X} 2-\mathrm{Y}$ & 0,050 & Linear \\
3. & $\mathrm{X} 3-\mathrm{Y}$ & 0,476 & Linear \\
\hline
\end{tabular}


Tabel 7 menunjukkan bahwa nilai sig. Deviation from linierity antara variabel penggunaan bahasa Inggris ragam lisan, intensitas pemanfaatan media dan kelengkapan sumber belajar dengan kemampuan listening $\geq 0,05$ maka dapat disimpulkan bahwa antara variabel penggunaan bahasa Inggris ragam lisan, intensitas pemanfaatan media dan kelengkapan sumber belajar dengan kemampuan listening comprehension terdapat hubungan yang linear.

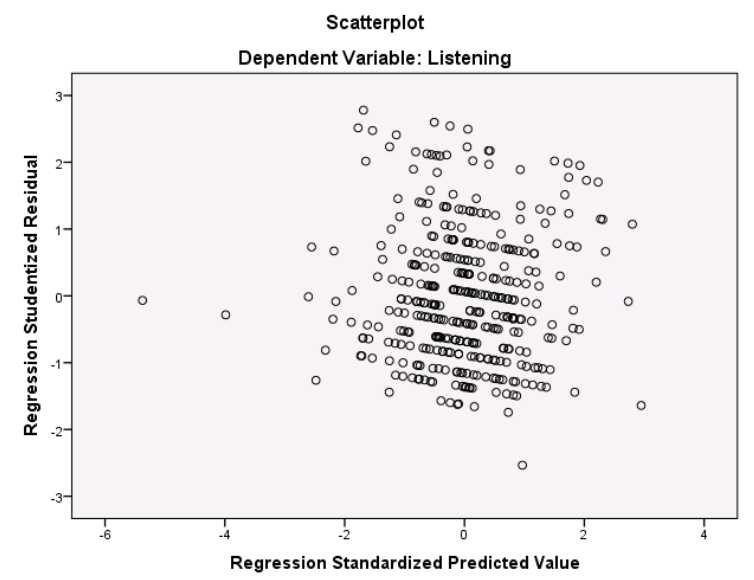

Gambar 1. Uji Heterokedastisitas

Uji heterokedastisitas (Gambar 1) dalam penelitian ini dilakukan dengan menggunakan uji Glejser. Jika grafik Scatterplot menunjukkan titik-titik menyebar secara acak dan tidak membentuk pola tertentu yang jelas, juga titiktitik tersebut menyebar di atas dan di bawah dari 0 pada sumbu Y maka tidak terdapat gejala heterokedastitas. Dengan melihat grafik Scatter di atas, jelas bahwa sumbu 0 pada sumbu Y. Maka dapat disimpulkan tidak terdapat gejala heterokedastisitas atau Ho diterima.

Tabel 8. Uji Multikolinearitas

\begin{tabular}{cccc}
\hline No. & Variabel & Tolerance & VIF \\
\hline 1. & X1 - Y &, 999 & 1,001 \\
2. & X2 - Y &, 998 & 1,002 \\
3. & X3 - Y &, 997 & 1,003 \\
\hline
\end{tabular}

Berdasarkan hasil dari perhitungan yang dilakukan dengan SPSS 20 menunjukkan bahwa tidak ada nilai Tolerance lebih besar dari 0,10 dan VIF yang kurang atau lebih kecil dari 10,00. Hal ini berarti tidak terjadi multikolinearitas dan tidak ada korelasi antara variabel-variabel independen.

\section{Uji Hipotesis}

Hasil dari Regresi Ganda menunjukkan

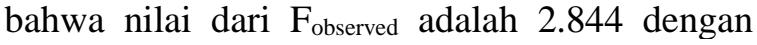
level signifikan 0.038 . Karena nilai signifikan $\alpha$ $\leq 0.05$, maka regresi yang terjadi telah membukti- kan bahwa penggunaan bahasa inggris ragam lisan Intensitas pemanfaatan media pembelajaran dan kelengkapan sumber belajar secara bersamasama mempengaruhi kemampuan listening comprehension.

Tabel 9. ANOVA ${ }^{\mathrm{a}}$

\begin{tabular}{llllll}
\hline Model & Sum & df & Mean & F & Sig \\
\hline Regresi & 1867,13 & 3 & 622,37 & 2,844 & 0,38 \\
Residual & 80094,6 & 366 & 218838 & & \\
Total & 81961,8 & 369 & & & \\
\hline
\end{tabular}

Tabel 10. Coefficients ${ }^{\mathrm{a}}$

\begin{tabular}{crrrr}
\hline Model & Beta & \multicolumn{1}{c}{$\mathrm{t}$} & sig & \multicolumn{1}{c}{ Part } \\
\hline X1 &, 126 & 2,433 &, 015 &, 126 \\
X2 & $-0,80$ & $-1,548$ &, 123 & $-0,80$ \\
X3 & $-0,14$ &,- 0277 &, 782 & $-0,14$ \\
\hline
\end{tabular}

Nilai dari koefesien korelasi parsial antara penggunaan bahasa Inggris ragam lisan dengan kemampuan listening comprehension (X1) adalah 0,126 Dengan level signifikan 0.038. karena nilai signifikan $\alpha \leq 0,05$. Hal ini menunjukkan bahwa penggunaan bahasa Inggris ragam lisan mempengaruhi kemampuan listening comprehension siswa.

Nilai dari koefesien korelasi parsial antara intensitas pemanfaatan media dengan kemampuan listening comprehension (X2) adalah $-0,080$. Dengan nilai signifikan $0,038 \leq 0,05$. Hal ini menunjukkan bahwa intensitas pemanfaatan media pembelajaran mempengaruhi kemampuan listening comprehension siswa

Nilai dari koefesien korelasi parsial antara kelengkapan Sumber belajar dengan kemampuan listening comprehension (X3) adalah -0,014. Dengan nilai signifikan kurang dari 0,05 . Hal ini menunjukkan bahwa kelengkapan sumber belajar mempengaruhi kemampuan listening comprehension siswa.

\section{Penggunaan Bahasa Inggris Ragam Lisan Mempengaruhi Kemampuan listening Comprehension Siswa}

Nilai dari koefesien korelasi parsial antara penggunaan bahasa Inggris ragam lisan dengan kemampuan listening comprehension adalah 0.126 dengan level signifikan 0.038 , karena nilai signifikan $\alpha \leq 0,05$. Hal ini menunjukkan bahwa penggunaan bahasa Inggris ragam lisan memengaruhi kemampuan listening comprehension siswa.

Pengaruh ini dapat dipahami, karena penggunaan bahasa Inggris ragam lisan merupakan salah satu pendukung penting dalam kemampuan listening comprehension siswa. Seperti yang 
dijelaskan oleh Wei (2013, p.192) bahwa penggunaan bahasa Inggris secara maksimal atau English-Only dapat meningkatkan keterampilan menyimak dan kosa kata siswa. Siswa juga lebih percaya diri ketika mereka menggunakan bahasa Inggris di kelas.

\section{Intensitas Pemanfaatan Media Pembelajaran Mempengaruhi Listening comprehension siswa}

Nilai dari koefesien korelasi parsial antara intensitas pemanfaatan media dengan kemampuan listening comprehension adalah $-0,080$. Dengan nilai signifikan $0,038 \leq 0,05$. Hal ini menunjukkan bahwa intensitas pemanfaatan media pembelajaran mempengaruhi kemampuan listening comprehension siswa. Pengaruh yang ada antara intensitas pemanfaatan media pembelajaran dan kemampuan listening comprehension mungkin saja terjadi karena penggunaan materi yang kurang tepat sasaran bagi pembelajaran listening. Penggunaan media yang sering digunakan mungkin saja lebih banyak menggunakan gambar-gambar, film kartun dan game yang tidak terdapat suara atau tidak menggunakan bahasa Inggris sehingga membuat listening comprehension tidak terintegrasi didalamnya.

Ah-Sanaky (2011, pp. 5-6) menyebutkan bahwa dalam proses pembelajaran di kelas perlu dipertimbangan media yang akan digunakan. Pertimbangan utama penggunaan media dalam pembelajaran harus sesuai dengan tujuan pengajaran, bahan pelajaran, metode mengajar, tersedia alat yang dibutuhkan, pribadi pengajar, minat dan kemampuan pembelajar dan situasi pengajaran yang sedang berlangsung.

Jadi, dengan demikian keterkaitan antara media pembelajaran dengan tujuan materi, metode dan kondisi pembelajar harus menjadi perhatian dan pertimbangan pengajar untuk memilih dan menggunakan media dalam proses pembelajaran di kelas, sehingga media yang digunakan lebih efektif dan efisien untuk mencapai tujuan pembelajaran, sebab media pembelajaran tidak dapat berdiri sendiri, tetapi terkait dan memiliki hubungan secara timbal balik dengan aspek tersebut.

\section{Kelengkapan Sumber Belajar Mempengaruhi Listening comprehension siswa.}

Nilai dari koefesien korelasi parsial antara kelengkapan Sumber belajar dengan kemampuan listening comprehension adalah -0,014. Dengan nilai signifikan kurang dari 0,05 . Hal ini menunjukkan bahwa kelengkapan sumber belajar mempengaruhi kemampuan listening comprehension siswa. Pengaruh yang terjadi antara kelengkapan sumber belajar dan kemampuan listening comprehension bisa saja terjadi karena kondisi riil anak di sekolah, penggunaan sarana dan prasarana yang ada baik di rumah maupun di sekolah tidak digunakan dengan tujuan pembelajaran di sekolah. Seperti penggunaan internet dan sarana hiburan seperti televisi. Kondisi ini hanya memberikan sedikit manfaat dan nilai pengalaman belajar yang konkret dan langsung karena penggunaan sumber belajar yang ada tidak digunakan untuk kepentingan pembelajaran di sekolah atau tidak sesuai dengan tugas belajar yang diberikan oleh pendidik.

\section{SIMPULAN}

Mengacu pada analisis data dalam penelitian ini dapat disimpulkan bahwa intensitas penggunaan bahasa Inggris ragam lisan, pemanfaatan media pembelajaran dan kelengkapan sumber belajar secara bersama-sama memengaruhi kemampuan listening comprehension siswa kelas VIII pada SMP di Kabupaten Sleman. Nilai signifikan dari tabel ANOVA atau uji $\mathrm{F}$ diperoleh 2,844 dengan nilai probabilitas atau $\mathrm{p}$ dari 0.038. Hasil dari analisis menunjukkan bahwa nilai probabilitas lebih rendah dari 0.05, maka dapat disimpulkan bahwa penggunaan bahasa Inggris ragam lisan, intensitas pemanfaatan media pembelajaran dan kelengkapan sumber belajar secara bersama-sama mempengaruhi kemampuan listening comprehension.

Intensitas penggunaan bahasa Inggris ragam lisan berpengaruh pada kemampuan listening comprehension siswa kelas VIII pada SMP di Kabupaten Sleman. Hal ini dapat dilihat padan nilai dari koefesien korelasi parsial antara penggunaan bahasa inggris ragam lisan dengan kemampuan listening comprehension adalah $\mathrm{r}=$ 0,126 sig. Dengan $p \leq 0,05$ dan nilai beta 0,126 . Hal ini menunjukkan bahwa korelasi positif yakni semakin tinggi intensitas penggunaan bahasa Inggris ragam lisan guru, maka semakin tinggi pula kemampuan listening comprehension siswa.

Intensitas pemanfaatan media pembelajaran berpengaruh pada kemampuan listening comprehension siswa kelas VIII pada SMP di Kabupaten Sleman. Nilai dari koefesien korelasi parsial adalah $r=-0,080$ dengan $p \geq 0,05$ dan nilai Beta sebesar -0,080. Kelengkapan sumber belajar berpengaruh pada kemampuan listening comprehension siswa kelas VIII pada SMP di Kabupaten Sleman.. Nilai dari koefesien korelasi 
parsial adalah $r=-0,014$ dengan $p \geq 0.05$ dan nilai Beta sebesar $-0,014$.

\section{DAFTAR PUSTAKA}

Ah-Sanaky, H. (2011). Media pembelajaran buku pegangan wajib guru dan dosen. Yogyakarta: Kaukaba.

Assapari, M. M. (2014). Teaching listening comprehension using interactive classroom listening performance. Cordova of Language Studies, 4 (2). Retrived from http://ejurnal.iainmataram.ac.id/index.php /cordova/article/view/141

Barber, M. \& Mourshed, M. (2007). How the world's best-performing school systems come out on top. London: McKinsey \& Company.

Benson, A., \& Odera, F. (2013). Selection and use of media in teaching Kiswahili language in secondary schools in Kenya. International Journal of Information and Communication Technology Research, 3(1).

Choirunnisa, S., \& Haryadi, H. (2015). Pengembangan media pembelajaran bahasa Inggris berbasis komputer untuk keterampilan menyimak bagi siswa SMA kelas X. LingTera, 2(2), 208 - 221. doi:https://doi.org/10.21831/lt.v2i2.7382

Djamarah, S.B., \& Zain, A. (2006). Strategi belajar mengajar. Jakarta: Rineka Cipta.

Dunkel, P \& Lim, P.L. (2006). Intermediate listening comprehension: Understanding and recalling spoken Heinle \& Heinle Pub.

Goh, C. C. M. (2002). Teaching listening in the language classroom. SEAMEO Regional Language Centre.

Harmer, J. (2003). The practice of English language teaching. New York: Longman.

Hsu, C. K., Hwang, G. J., Chang, Y. T., \& Chang, C. K. (2013). Effects of video caption modes on English listening comprehension and vocabulary acquisition using handheld devices. Journal of Educational Technology \& Society, 16(1), 403-414.

Krashen, S.D. (2002). Second language acquisition and second language learning. California: Pergamon Press Inc.
Krejcie, R. V., \& Morgan, D. W. (1970). Determining sample size for research activities. Educational and Psychological Measurement, 30(3), 607-610.

Leveridge, A. N., \& Yang, J. C. (2013). Testing learner reliance on caption supports in second language listening comprehension multimedia environments. ReCALL, 25(2), 199-214.

Maharani, T., \& Astuti, E. S. (2018). Pemerolehan bahasa kedua dan pengajaran bahasa dalam pembelajaran BIPA. Jurnal Bahasa Lingua Scientia, 10(1), 121-142. doi:10.21274/ls.2018.10.1.121-142

Mulyasa, E. (2002). Manajemen berbasis sekolah konsep strategi dan implikasi. Bandung: PT. Remaja Rosda Karya.

Prayitno, J. (2014). Ragam bahasa lisan dan tulisan siswa kelas $\mathrm{X}$ jurusan akomodasi perhotelan SMK Negeri 3 Bogor Tahun Pelajaran 2013-2014. LOKABASA, 5(1). doi: http://dx.doi.org/10.17509/jlb.v5i1.3156

Qurniawati, Z., \& Nurhayati, E. (2015). Kerancuan fono-ortografis dan otofonologis pada bahasa Jawa ragam lisan dan tulis dalam berita bahasa Jawa di Jogja TV. LingTera, 2(1), 93 - 100. doi:https://doi.org/10.21831/lt.v2i1.5411

Schultz, K. (2003). Listening: A framework for teaching across differences. Teachers College Press.

Sinaga, A. E. B. (2017). Interferensi cakap Karo dalam penggunaan bahasa Indonesia lisan siswa kelas XI IPS SMA Katolik 2 Kabanjahe tahun pembelajaran 2016/2017. Dissertation, Universitas Negeri Medan.

Subali, B., \& Suyata, P. (2012). Pengembangan item tes konvergen dan divergen. Yogyakarta: Diandra Pustaka Indonesia.

Sudjana, N \& Rivai, A. (2010). Media pengajaran (penggunaan dan pembuatannya). Bandung: Sinar Baru Algensindo Offset.

Wei, D. D. (2013). The implementation of English-only policy in the tertiary EFL context in Taiwan. Indonesian Journal of Applied Linguistics, 2(2), 187-198. 